\title{
A Novel Method for Attainment Measurement of CO's and PO's for Tier-II Institutions
}

\author{
Mr. Kiran B. Malagi ${ }^{l}$,Mr. Kumar Swamy V. ${ }^{2}$,Dr.B.S.Anami ${ }^{3}$ \\ ${ }^{1}$ Asst Professor, Department of CSE, KLEIT, Hubballi, \\ 2 Asst Professor, Department of EEE, KLEIT, Hubballi, \\ ${ }^{3}$ Principal, KLEIT, Hubballi, \\ ${ }^{1}$ malagikiran@gmail.com \\ 2 swamy_bvbdigital@yahoo.co.in \\ 3 anami_basu@hotmail.com
}

\begin{abstract}
National Board of accreditation accredits various programs of technical institution in India. It is a quality assurance process that determines whether the educational objectives set by the institutes are being continually and honestly perceived or not. In this process, a graduate is expected to have certain qualities, during and after the completion of his/her graduation and are called Program Outcomes (PO) and are also referred to as Graduate Attributes. In this paper, we have proposed a novel method for measurement of attainment of CO's and PO's for Tier-II institutions. The measurement of attainment of COs and POs is illustrated for a course in Electrical and electronics engineering program. The proposed method helps in preparing effective lesson plan, drawing quality question paper.
\end{abstract}

Keywords: Measurement, Attainment, Course Outcomes, Program Outcomes, Graduate Attributes.

\footnotetext{
Mr. Kiran B. Malagi ${ }^{l}$

${ }^{1}$ Asst Professor, Department of CSE, KLEIT, Hubballi, ${ }^{1}$ malagikiran@gmail.com
}

\section{Introduction:}

It is often reported that, there is tremendous growth in education providers, the need for quality assurance becomes essential. There is a gap between industry and academia, because there is lack of role-ready engineers required by the industry. So the traditional method of education system itself needs to be changed. A drift is required from teacher centric to student centric education system. In teacher centric education system, a teacher defines the content that they intend to teach, the approach used for content delivery and content assessment. The focus is on what student is expected to be able to do to pass a module or a program. In student centric education system, the focus is laid on what the students are expected to be able to demonstrate at the end of a module or program or we can say after the learning period.

In order to meet these challenges in India, UGC formed National Assessment and Accreditation Council (NAAC), and carries out Institute level Accreditation and All India Council for Technical Education (AICTE) set a committee called National Board of Accreditation (NBA), which accredits the Technological Programs. All the Technical educational institutions apply for NBA to avail fiscal benefits. In this regard, every institute has to set vision, mission, and Program educational objectives, Program Outcomes (PO), Course Outcomes (CO) and Topic Learning Outcomes (TO). These parameters need to be assessed by the institute at regular intervals, namely, Topic learning outcomes after the topic completion, Course learning outcomes at the time of internal assessments and Semester examination, Program outcomes are assessed at the time of completion of graduation. PEO are assessed based on the performance of the graduates in the society, playing different roles. At the basic level, we need to set the COs in order to educate, what a student will be able to do after completion of the course. These COs are contributing in attainment of POs. In this paper, we are concentrating on how to assess the attainment of COs and POs (in tern Graduate attributes). We have Performance Indicator Codes in short called as PI codes, which indicate the program outcome in general and Outcome element in specific being focused by that particular CO. In order to 
know the state-of-the-art in attainment measurements in

particular IA is obtained. At the end of the semester outcome based education, we have carried out a literature consolidating the average of all IA, Attainment level is

\begin{tabular}{|c|c|c|c|c|c|}
\hline $\begin{array}{l}\text { SI } \\
\text { no }\end{array}$ & Authors & $\begin{array}{l}\text { Parameters } \\
\text { assessed }\end{array}$ & $\begin{array}{l}\text { Approach } \\
\text { used }\end{array}$ & Assessment & Remarks \\
\hline 1 & Izham et al. & $\begin{array}{l}\text { Course Outcomes } \\
(\mathrm{CO})\end{array}$ & Quantitative & $\begin{array}{ll}\text { - } & \text { Final exam } \\
\text { - } & \text { Quiz } \\
\text { - Assignment } \\
\text { - } & \text { Projects } \\
\end{array}$ & $\%$ of weightage has been assigned \\
\hline 2 & Savita $S$ et al. & $\begin{array}{l}\text { Program Outcome } \\
(\mathrm{PO})\end{array}$ & Quantitative & $\begin{array}{ll}\text { - } & \text { Review literature } \\
\text { - } & \text { Design process } \\
\text { - } & \text { Tabulation \& Result }\end{array}$ & $\%$ of weightage has been assigned \\
\hline 3 & Osman et al. & $\mathrm{CO}$ & Qualitative & $\begin{array}{ll}\text { - } & \text { Final exam } \\
\text { - } & \text { Projects } \\
\end{array}$ & Considered for only 1 lab course \\
\hline 4 & Masni et al & $\mathrm{CO}$ and $\mathrm{PO}$ & Quantitative & $\begin{array}{l}\mathrm{A}=\mathrm{n} / \mathrm{N} * 100 \% \\
\text { Where } \\
\mathrm{A}=\mathrm{CO} / \mathrm{PO} \text { attainment, } \\
\mathrm{n}=\text { total students achieve } \\
\text { above } 50 \% \\
\mathrm{~N}=\text { total students }\end{array}$ & $\begin{array}{l}\text { Considered for only the avg marks } \\
\text { and final formula has been given. }\end{array}$ \\
\hline 5 & Yuzainee et al. & PO & Quantitative & $\begin{array}{l}\text { Mean and standard } \\
\text { deviation }\end{array}$ & $\begin{array}{l}\text { Considered for both Lab and } \\
\text { theory course }\end{array}$ \\
\hline 6 & Makinda et al. & $\mathrm{CO}$ and $\mathrm{PO}$ & Quantitative & Average marks & $\begin{array}{l}\text { Considered only One question } \\
\text { mapping to one individual CO for } \\
\text { final attainment }\end{array}$ \\
\hline 8 & Zulfadli et al. & $\mathrm{CO}$ & Quantitative & $\begin{array}{l}\text { - } \text { Final exam } \\
\text { - Quiz } \\
\text { - Assignment }\end{array}$ & $\begin{array}{l}\text { No discussion about overall CO } \\
\text { attainment over the class }\end{array}$ \\
\hline 9 & Sam Chu et al. & $\mathrm{CO}$ and $\mathrm{PO}$ & Qualitative & NA & $\begin{array}{l}\text { Grading system at the beginning } \\
\text { and at the End of sem/year }\end{array}$ \\
\hline 10 & $\begin{array}{l}\text { Kiran et al } \\
\text { (Proposed } \\
\text { methodology) }\end{array}$ & $\mathrm{CO}$ & Quantitative & Internal assessment & $\begin{array}{l}\text { Attainment of COs and POs from } \\
\text { micro level considering each bit of } \\
\text { the question in the IA question } \\
\text { paper. }\end{array}$ \\
\hline
\end{tabular}

survey.

From Table 1, we have found that, the work done till now in this area of assessing the attainment of COs and POs is done only for the autonomous institutions, where the liberty of setting curriculum, syllabus, content delivery and also setting evaluation strategy is with the autonomous institute itself, whereas the proposed work addresses this issue from the affiliated institute's perspective. As an affiliated institute, care is taken only in lesson delivery and assessing the attainment of COs and POs by internal assessments. Evaluation of answer scripts (Final examination) is done at the university level. This work assesses the attainment of COs and POs in micro level considering each bit of the question in the Internal Assessment (IA) question paper and every internal assessment of all the course offered in that semester. Also PO attainm obtained.

The paper is organized into four sections. Section 2 deals with proposed methodology. Results and discussions are given in section 3 and conclusion is given in section 4 .

\section{Proposed Methodology:}

In Fig 1 Teaching Learning Process cycle is shown. This consists of three phases, namely, Planning Phase, Action Phase and lastly the Measure and Analysis phase. The first one being the Planning phase the course Outcome and Objectives are set and the curriculum is designed. Also the method of assessment and schedule of assessment is done. 


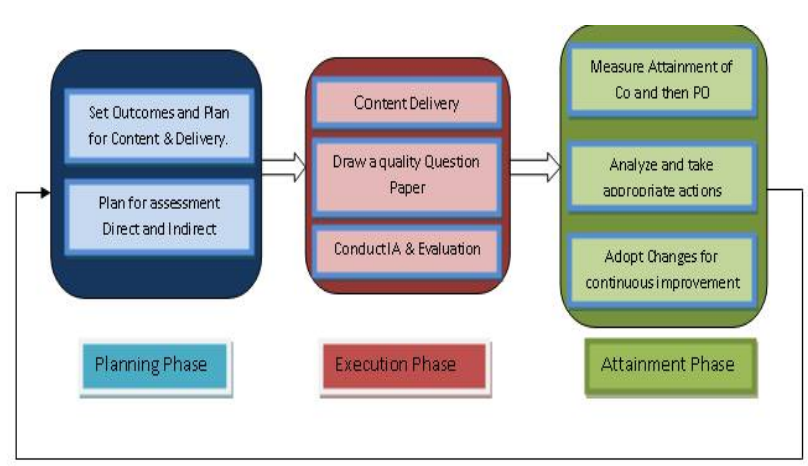

Fig 1: Teaching- Learning Process Cycle

The second phase is an Action phase, where content delivered the question paper for assessment is drawn and internal assessments are conducted and evaluation is done.

In the third phase, Measure and Analysis phase, based on the marks obtained by the students we need to measure the COs and POs attainment, analyze and take appropriate actions so that there is a continuous improvement. There are two methods for measurement of attainment of outcomes, one is the direct method and another is an indirect method of assessment. The method proposed pertains to the direct method, where analysis done is based on the Marks obtained by students across the whole class for that course. In this regard we are proposing some practices followed in each phase.

\subsection{Planning phase:}

This phase consists of measurement of course outcomes and preparation of lesson plans.

\subsubsection{Course Outcomes:}

Course outcomes can be drawn by combining few topics learning outcome (TLOs). It is advised to have 5-6 COs per course in a program. COs should be drawn in such a way that they should be generic enough to state the outcomes rather than speaking very much specific about the syllabi set by the BOS/University. Also when we are setting the question paper for individual internal assessment, the question paper should address maximum COs. Over a semester the entire COs should be assessed for each and every student in that course.

As an affiliated institution (Tier II), we do not frame curriculum and syllabi, we focus upon setting up the Course outcomes to meet the graduate attributes. Over a program we should be able to address all the POs. We can't expect an individual course will meet all POs. With this in mind whenever an IA is conducted average of student marks for an individual bit of the question is taken and hence we say that average is the total $\mathrm{CO}$ attainment by that question by the class. Similarly other bits of questions and their $\mathrm{CO}$ attainment are calculated. All questions with the same $\mathrm{CO}$ are added and then average of these gives the total attainment of the $\mathrm{CO}$ through the question paper.

\subsubsection{Lesson plans:}

In the lesson plans the COs, CO-PO Mapping, TLOs (Topic Learning Outcomes), hour wise distribution of contents are included. Also Unit wise review questions and their respective TLO, Blooms level and PI codes are all mentioned. This help the student to be aware about all these parameters of OBE .Students will be familiar with the kind of questions appearing, the content to be written to get full marks for that question, time management in exam etc. As CO, PO( PI Codes ) and also Blooms levels are the measures to say a question paper as a quality question paper, we include the above said parameters in lesson plans and distribute it to students every semester with all courses for that semester at the start of semester.

\subsection{Quality of Question paper:}

Question paper must consist of questions which can be answered in stipulated time period with various levels of learning (BLOOMS levels). It is hard to expect a student answer 3-4, L3 level questions in 1 hour. Template of a question paper is shown below where Questions, their respective $\mathrm{CO}$, Marks allotted, Blooms level and PI code are mentioned. Table 2 fives a Question paper format of signals and systems course for EEE program.

Table 2: A Model question paper

\begin{tabular}{|c|c|c|c|c|c|c|}
\hline $\begin{array}{l}\text { Qtn } \\
\text { No }\end{array}$ & $\begin{array}{l}\text { Sub } \\
\text { Qtn }\end{array}$ & Question & Marks & BL & CLO & $\begin{array}{c}\text { PI } \\
\text { code }\end{array}$ \\
\hline \multirow{3}{*}{1.} & a & $\begin{array}{l}\text { Define signal and system. Explain energy and power signal in } \\
\text { detail. }\end{array}$ & 06 & L1 & $\mathrm{i}$ & 105 \\
\hline & $\mathrm{b}$ & Outline the even and odd component of the signal shown below. & 07 & L2 & $\mathrm{i}$ & 105 \\
\hline & c & $\begin{array}{l}\text { Outline the following signal } \mathrm{x}(\mathrm{t})=\mathrm{A} \sin (\mathrm{t}) \text { for }-\infty<\mathrm{t}<\infty \text {. Also } \\
\text { show whether the signal is energy or power? }\end{array}$ & 07 & L2 & i & 105 \\
\hline \multirow[b]{2}{*}{2.} & a & $\begin{array}{l}\text { For the signal shown below, outline i) } x(3 t) \text { ii) } x(3 t+2) \text { iii) } \\
x(-2 t-1) \text { iv }) x(2 t-4) v) x(3 t)+x(2 t-4)\end{array}$ & 10 & L2 & i & 105 \\
\hline & $\mathrm{b}$ & $\begin{array}{l}\text { The impulse response of the circuit is given as } h(t)=e^{-t} u(t) \text {. } \\
\text { This circuit is excited by an input of } \\
x(t)=e^{-3 t}\{u(t)-u(t-2)\} \text {. Show the output of the circuit. }\end{array}$ & 10 & L2 & iii & 2a1 \\
\hline \multirow{3}{*}{3.} & a & Show the equation $\mathrm{y}(\mathrm{n})=\mathrm{x}(\mathrm{n}) * \mathrm{~h}(\mathrm{n})$ & 06 & L2 & ii & $2 \mathrm{a} 1$ \\
\hline & $\mathrm{b}$ & $\begin{array}{l}\text { Find the following for a continuous time system, } \\
\begin{array}{lll}=10 x(t)+5 \text {, for } & \text { i) stability ii) Memory } & \text { iii) Causal } \\
\text { Linearity v) Time invariant.| } & \end{array}\end{array}$ & 07 & L1 & $\mathrm{i}$ & $1 \mathrm{c5}$ \\
\hline & c & $\begin{array}{l}\text { Convolve the following two signals } x_{1}(n) \text { and } x_{2}(n) \text { to find } y(n) \text {. } \\
\text { Given } x_{1}(n)=\{1,2,3\} \text { and } x_{2}(n)=\{1,2,3,4\} \text {. }\end{array}$ & 07 & L1 & ii & $3 \mathrm{a}^{2}$ \\
\hline
\end{tabular}

\subsubsection{Performance Indicator Codes:}

Every program has to set its Performance Indicators by considering the areas upon which their syllabi is spread over according to the Graduate attributes specified by NBA. The twelve graduates attributes which are also referred to as Program outcomes are listed in Table 3. 


Percentage distribution of CO over all POs=
Contribution of CO to individual PO $* 100$
$\sum$ Extent of Contribution of CO to all POs
........ (3)

Now the calculation of Actual PO attainment has to be done. The formula used is:

Attainment of POs by individual CO $=($ Avg of Class
CO Attainment $*$ Expected PO attainment) $/ \quad 100$

This gives the attainment of POs that are mapped to one individual $\mathrm{CO}$. In the same fashion All $\mathrm{CO}$ and PO attainments are calculated. Then the POs attainment is added and average is taken. That is the total attainment of POs from that particular internal assessment.

These calculations result into attainment from only one IA for only one particular course. The same procedure has to be followed for all the IAs and all the courses in that semester and average of these becomes the attainment from the courses in that semester. The Procedure is continued for one batch of students and consolidated report needs to be generated where cumulative attainment shall be changing based on the performance of the students in that semester.

\section{Results and Discussions:}

Attainment of $\mathrm{CO}$ and $\mathrm{PO}$ is measured considering the Topic learning outcomes also. So attainment that is being spoken here is the guaranteed minimum attainment. An excel sheet with all the necessary formulae for measuring attainment is prepared. The faculty after completion of evaluation of IA booklets in his course, has to enter the marks in excel sheet. Also he has to enter the $\mathrm{CO}$ to which the question meets, the maximum marks for that bit of question, and CO-PO mapping done in lesson plan. All other calculation for one IA is done with the formulae proposed.

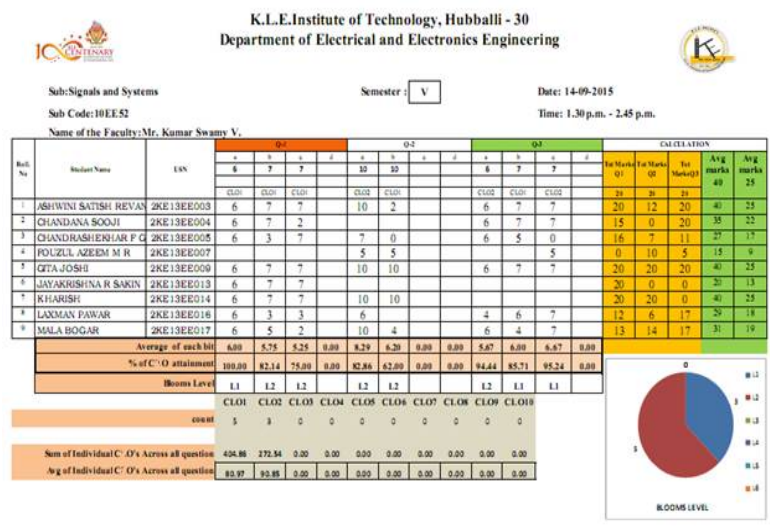

Figure 2: Snap shot of Excel Sheet for marks entry and CO attainment for S\&S course of EEE Program.
The Figure 2 is a snapshot showing Course outcome attainment and Figure 3 is Program outcome attainment. In Figure 2 the rows represent performance by a student and his average by taking best of two marks out of three and column represents the performance of the all students across a class in that bit of question. With the data available Average of each bit is obtained and then the percentage of $\mathrm{CO}$ attainment is calculated. Faculty enters the Blooms level for which a graph is drawn demonstrating the level of question paper. Then Average $\mathrm{CO}$ attainment is obtained for all COs across all questions.

In the question paper considered here $\mathrm{CO} 1$ and $\mathrm{CO} 2$ are measured and attainment level is 80.97 and 90.87 respectively. Hence this is a substantial attainment. We have a measure that if $\mathrm{CO}$ attainment is from $0-35 \%$, it's a poor attainment and hence the topic has to be readdressed to the class. If the range is in between $36-60$ it is moderate attainment. Then in tutorial classed the topic needs to be discussed. If the attainment range is from 61 to 100 this is a substantial attainment.

Now for measuring PO attainment, we have taken the table where CO-PO mapping table is prepared in the lesson plans. Consider the Figure 2, in which we are showing the CO-PO mapping, the expected $\mathrm{PO}$ attainment and the actual PO attainment from that particular IA.

In the Figure 3, for one $\mathrm{CO}$ we have three Rows. The first row corresponds to the contribution of $\mathrm{CO}$ to an individual PO. Second row represents the expected PO attainment and the third actual PO attained.

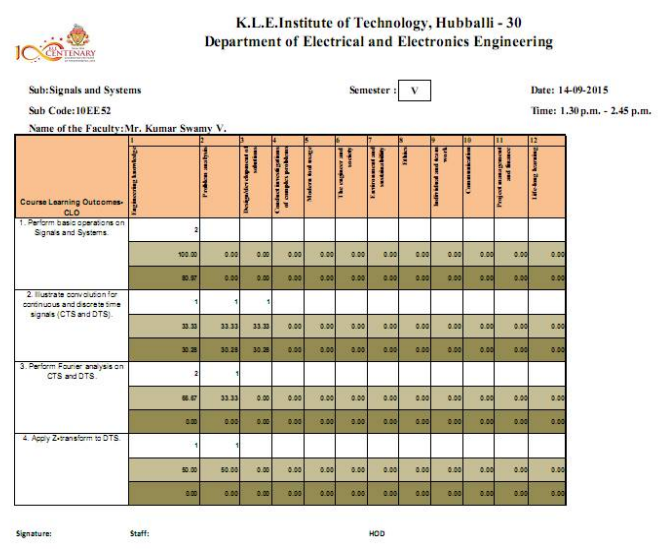

Figure 3: Snap Shot of Excel Sheet for PO attainment.

As the contribution of CO1 is only to PO1 $100 \%$ is the expected attainment. From the IA analysis we have achieved 89.97. $\mathrm{CO} 2$ is contributing low to first $3 \mathrm{POs}$, hence $33.33 \%$ is the contribution of $\mathrm{CO} 2$ for $\mathrm{PO} 1, \mathrm{PO} 2$ and $\mathrm{PO} 3$ and is the expected attainment from that $\mathrm{CO} 2$ also. Actual attainment is 30.28 in each PO. This is the result that we have obtained. By considering the consolidated result over a semester, $\mathrm{CO}$ and $\mathrm{PO}$ attainment over a course are measured. 


\section{CONCLUSIONS:}

NBA has become mandatory for engineering colleges both autonomous and affiliated. The proposed method of attainment measurement is developed for tier-II institutions which are affiliated to a university. The method has considered TLOs, CO's, assignment of performance indicators for measuring attainment of each $\mathrm{CO}$ and PO. This quantitative assessment is unlike prevailing qualitative approaches in assessing a program. The method also depicts how the TLOs, COs and POs are interdependent. The work is useful in preparing effective lesson plans, and drawing quality question papers. Another intangible benefit is that one feels confident in giving the details for criteria-2 and criteria-3 of Self Assessment Report of NBA document for TIER II institutions. The method is illustrated with "Signals and Systems" course of BE program in Electrical and Electronics engineering program. However the proposed method of measurement is useful across the different programs, namely, medicine, agriculture and management etc.

\section{Acknowledgement:}

Authors wish to thank to all $\mathrm{t}$ he faculty members of K.L.E. Institute of Technology, Hubli and K.L.E. Technological University, Hubli, whose suggestions helped us to propose this novel approach .

\section{References}

1. .Makinda J.,Bolong N., Mirasa A.K and Ayog J.L., "Assessing the Achievement of Program Outcome on Environment and Sustainability: A Case Study in Engineering Education" 2nd Regional conference on Campus sustainability: Capacity building in Enhancing Campus sustainability. University Malaysia Sabah, Malaysia, 7th-8th April 2015.

2. Izham Zainal Abidin, Adzly Anua and Norshah Hafeez Shuaib," Assessing the attainment of course outcomes (CO) for an engineering course" Proceedings of the 2nd International Conference of Teaching and Learning INTI University College, Malaysia (ICTL 2009)

3. Norain Farhana Ahmad Fuaad, Ruhizan Bt. Mohammad Yasin and Norngainy MohdTawil, "Achievement of the Program Outcomes in Outcomes Based Education Implementation - A Meta Analysis", Proceedings of the 2014 International Conference on Industrial Engineering and Operations Management Bali, Indonesia, January 7 - 9, 2014.

4. Zulfadli, Shamsul Anuar Mokhtar, Sayani Puteh, Siti Mashitah Shamsul Anuar ," OBE Measurement System in Malaysian Institute of Information Technology Universiti Kuala Lumpur” 2014 Fifth International Conference on Intelligent Systems, Modelling and Simulation, pp 12-19.2014.

5. Sam Chu, Natalie Fong, Si Ying Tan," Applying outcomes-based teaching and learning framework in the BSc Information Management Program in the Faculty of Education", Intl conf on enhancing Learning Experiences in Higher Education, Hong Kong., 2-3, December 2010.
6. S.A.Osman, A. Mutalib, M.A.Khoiry, "Measuring Students' Achievement in Fundamental Course of Civil and Structural Engineering Degree Programme" Latest advances in educational technologies, ISBN:978-1-61804-093-0.

7. M.S. Jaafar, N. K. Nordin, R. Wagiran, A. Aziz, M.J.M.M. Noor, M.R. Osman, J. Noorzaei and F.N.A. Abdulaziz, " Assessment Strategy for an Outcome Based Education", Universiti Putra Malaysia, 43400 UPM-Serdang, Malaysia

8. Masni-Azian, A. Rahimah, A.H. and M.S., Othman, "Towards OBE: A Case Study of Course Outcome (CO) and Programme Outcome (PO) Attainment for Product Design and Development Course" OSR Journal of Research \& Method in Education (IOSRJRME) e-ISSN: 2320-7388, p-ISSN: 2320-737X. Volume 4, Issue 2 Ver. III (Mar-Apr. 2014), PP 55-61.

9. Suresh D. Mane, "Accreditation of UG Engineering Programmes in India: Enhanced Role of Teaching Fraternity", International Journal of Scientific Engineering and Applied Science (IJSEAS) - Volume1, Issue-6, September 2015.

10. Zamri Mohamed, Mohd Yusof Taib, M.S. Reza, "Assessment Method for Course Outcome and Program Outcome In Outcome Based Education (OBE)", Proceedings of MUCET2010 Malaysian Technical Universities Conference on Engineering and Technology, June 28-29, 2010.

11. Norshah hafeez shuaib,Adzly anuar, Ramesh singh and Mohd zamri yusoff, "Implementing continual quality improvement (CQI) process in an outcomebased education (OBE) approach", Proceedings of the 2nd International Conference of Teaching and Learning, 2009.

12. H. R. Bhagyalakshmi D., Seshachalam, S. Lalitha, "Program Outcome Attainment Through Course Outcomes: A Comprehensive Approach", Proc of the Intl Conference on Transformations in Engineering Education, pp 279-287, 2014.

13. Ramchandra, S., Maitra, S, MallikarjunaBabu, K."Method for estimation of attainment of program outcome through course outcome for outcome based education", 2014 IEEE International Conference on MOOC, Innovation and Technology in Education (MITE),pp 7 - 12, 2014.

14. www. nbaind. org

15. Sandra Staklis, Steven Klein, "Technical Skill Attainment and Post-Program Outcomes: An Analysis of Pennsylvania Secondary Career and Technical Education Graduates Technical ", National Research Center for Career and Technical Education University of Louisville.

16. H. Basril, A. B. Che Man, W. H. Wan Badaruzzaman \& M. J. M. Nor, "Malaysia And The Washington Accord: What It Takes For Full Membership", International Journal of Engineering and Technology, Vol. 1(1), 2004, pp. 64-73.

17. Yildirim, TP, L. Shuman and M. Besterfield-Sacre, "Model Eliciting Activities: Assessing Engineering Student Problem Solving and Skill Integration 
Processes," International Journal of Engineering Education, 26(4), 2010, pp. 831-845.

\section{About Authors:}

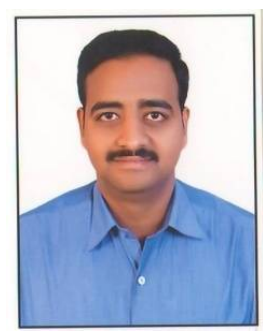

Mr. Kiran B. Malagi, Assistant professor, K. L. E. Institute of Technology. Hubli, Karnataka, India. He has obtained B E and Masters degree in Computer Science and Engineering, in the year 2005 and 2010 respectively. He worked as Head of Computer Science Department, K.L.E. Society's C.B. Kolli polytechnic, Haveri from 2005-2010 . From 2010 onwards he is working in K.L.E. Institute of Technology, Hubli. He has a total of 10 years of experience. His areas of interest are Data base Management system, Data Mining, Web mining, Computer Graphics and software Engineering.

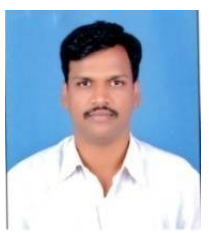

Mr. V. Kumar Swamy is presently working as Assistant Professor in Department of Electrical and Electronics Engineering, K.L.E. Institute of Technology, Hubli. He completed his BE (Electrical and Electronics) in 2006 and M.Tech (Digital Electronics) in 2009.

$\mathrm{He}$ is pursuing his $\mathrm{PhD}$ from VTU, Belgaum. He has total 7 years of experience.

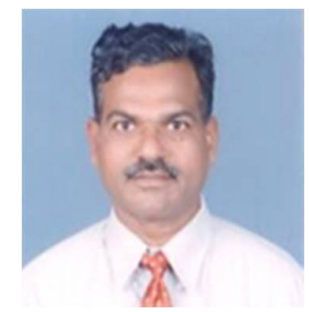

Dr. Basavaraj S. Anami Principal. K. L. E. Institute Of Technology. Hubli, Karnataka, India. He has obtained B E degree in Electrical Engineering, Masters degree in Computer Science and Ph.D in Computer Science in the year 1981,1986 and 2003 respectively. He worked as faculty of Computer Science and Engineering Department, Basaveswar Engineering College , Bagalkot, in various designations from 1983 to 2008. His research areas of interest are Image Processing and Pattern Recognition, Character recognition, Fuzzy systems and Neural Networks He has published 100 plus research papers in peer reviewed International Journals and conferences 